ARTICLE

https://doi.org/10.1057/s41599-019-0346-2

\title{
Precision medicine in the era of CRISPR-Cas9: evidence from Bosnia and Herzegovina
}

\author{
Sabina Semiz (1) ${ }^{1,2 \star} \&$ Philip C. $A k a^{3}$
}

\begin{abstract}
This article explores the possibilities and challenges of genetic testing, genetic counseling, and genome editing (collectively referred to in this piece as precision medicine) in Bosnia and Herzegovina, in the era of CRISP-Cas9. It is informed by recent developments in the field which reached new heights in the radar of global awareness in the wake of the research scandal from China in November of 2018. The scandal generated intense debates, some of it still ongoing, regarding the appropriate boundaries for scientific research on human DNA. Bearing on independent developments within this country, complemented with global events, the article covers several grounds related to the topic, including: the nature and limits of emerging legislation; measures of genetic testing and genetic counseling; public engagement meant to increase awareness among stakeholders, beginning with the public, regarding these novel technologies; and corresponding bioethical and social implications. $\mathrm{BH}$ decision makers must work to ensure that socioeconomic factors do not pose obstacles to healthcare access, including matters bordering on precision medicine, and they must strive to realize standards for citizens, whether in healthcare delivery, research, or general educational services, that do not lag behind the rest of Europe. The route to reaching these governance goals will be through well-timed legislation, level-headed implementation, and diligent legislative oversight of the work of administrative agencies.
\end{abstract}

\footnotetext{
${ }^{1}$ College of Medicine and Health Sciences, Khalifa University, PO Box 127788, Abu Dhabi, UAE. 2 Faculty of Engineering and Natural Sciences, Internationa University of Sarajevo, 71210 Ilidža, Bosnia and Herzegovina. ${ }^{3}$ Faculty of Law, International University of Sarajevo, 71210 Ilidža, Bosnia and Herzegovina. *email: sabinasemiz@hotmail.com
} 


\section{Introduction}

enetic testing and counseling promote early detection that can serve to prevent the occurrence of a disease. They further use a patient's unique genetic profile with distinctive genetic signatures and biomarkers associated with the disease to target medical treatment that is tailored for an individual patient. By offering increased opportunities for improving diagnoses of diseases and developing targeted drugs, these novel techniques complement increased global efforts to implement precision or personalized medicine (PM) in medical practice. These recently developed biotechnologies allow genetic material to be precisely added, removed, or changed at particular locations in the affected DNA. By enabling scientists to change the DNA of an individual for targeted treatment, genome (or gene) editing marks an important step in patient-tailored medicine.

However, some good things sometimes come with a downside. Although tools of precision medicine, such as genetic testing, genetic counseling, and gene editing, represent major breakthroughs key to the future of medicine, they come with ethical, legal, and social issues (ELSI) associated with potential disparities in treatments and overall healthcare access, based on an individual's genetic profile (2018, Sankar and Parker, 2017, Adams and Petersen, 2016). Another factor impeding efficient employment of precision medicine is the high cost of these novel technologies that can exacerbate existing healthcare inequalities, particularly in low-income and middle-income countries (Iriart, 2019). Given these problems, recent studies recommend that efficient applications of PM in health system should, in addition to addressing the relevance of patients' genetic testing and counseling, also consider factors like social and cultural variables, potential racial and ethnic disparities (Mensah et al., 2019, Belisle-Pipon et al., 2019, Canedo et al., 2019), as well as legislative and regulatory framework (Duardo-Sanchez and De Miguel Beriain, 2018)

This article explores the possibilities and challenges of precision medicine, particularly genetic testing, genetic counseling, and genome editing, in Bosnia and Herzegovina (BH), in the era of CRISPR-Cas9 [Clustered Regularly Interspaced Short Palindromic Repeats and CRISPR-Associated Protein 9]. The paper has six sections, in addition to this introduction. Section "Challenges of genome editing in the era CRISPR-Cas9" traces the challenges of genome editing in the era of CRISPR-Cas9, including the factors that differentiate CRISPR-Cas from other gene editing techniques, the research scandal from China in Fall of 2018 involving the use of this technology, attempts by the international scientific community since then to develop guidelines for decision making on the responsible use of human genome-editing research, and the result of those efforts. Section "Genetic testing in Bosnia and Herzegovina" chronicles achievements in genetic testing, Section "Genetic counseling in Bosnia and Herzegovina" on genetic counseling, and Section "Public engagement in Bosnia and Herzegovina" on public engagement. Section "Legal framework" discusses the legal framework in $\mathrm{BH}$ related to precision medicine, particularly genetic testing, genetic counseling, and gene editing. The placement of this material in the penultimate portion of the paper is an act of organization that does not in any way minimize the key role of lawmakers and national regulation in precision medicine. Section "Conclusion" concludes the article.

\section{Challenges of genome editing in the era of CRISPR-Cas9}

Genome editing involves a set of technologies that enables scientists to change the DNA of an individual for targeted medical treatment. What makes genome editing a matter of great interest to the scientific community-but also as well to the general public -is its potential for clinical applications in the prevention and treatment of a wide range of diseases, including monogenic disorders, like hemophilia, sickle cell anemia, and cystic fibrosis, and complex diseases, like cancer, cardiovascular disease, diabetes, HIV/AIDS, and mental and neurological disorders (White and Khalili, 2016, Kc and Steer, 2019, Porteus, 2019). Much research today on genome editing is designed to better understand diseases by using cultured cells and animal models, while scientists work to gauge the safety and effectiveness of these approaches for human use (Isa et al., 2019, Ma et al., 2019).

Several technologies are employed for genome editing, including the protein-based nuclease systems, such as meganucleases, zinc finger nucleases (ZNFs), and transcription activator-like effector nucleases (TALENs) (Khan, 2019). The most recent in the lineup of techniques and the approach today generating tremendous excitement within the scientific community is CRISPR-Cas9. Since its power was first demonstrated in 2012, CRISPR-Cas9 has shown a capacity to transform research in genetics (White and Khalili, 2016, Kc and Steer, 2019), because, compared to other techniques, this approach appears to be faster, more precise, more efficient, and more cost-effective (Doudna and Charpentier, 2014, Baliou et al., 2018). CRISPR-Cas9 was adapted from the natural defense mechanisms in bacteria, one known to capture pieces of DNA from invading viruses (Wright et al., 2016, Bikard et al., 2012). CRISPR-Cas9 appears to be superseding ZFNs and TALENS as gene editing technology of choice for many scientists and has a high potential to trigger ground-breaking innovations not only in biology and medicine, but also in fields like agriculture (Bilichak et al., 2020).

However, the technology is associated with a number of obstacles that raise question regarding its efficiency in clinics and ultimately its safe applications in humans. One of these is avoidance of off-target effects (White and Khalili, 2016, Shah et al., 2019). A recent study suggested that CRISPR technology is more susceptible to off-target effects than ZNFs and TALENs (Heintze et al., 2013), an occurrence which presents a major challenge in its clinical application (Mei et al., 2016). Another obstacle centers on delivery of editing system to the targeted cells, due to the fact that nucleases may induce immune response and tumorigenicity (Shim et al., 2017). These concerns have generated intense debates among stakeholders across the world, among them: the scientific community, governmental bodies, and policy makers. These debates reached a highpoint recently when $\mathrm{He}$ Jiankui, a Chinese biophysicist, disclosed in November of 2018 that he used the CRISPR-Cas9 technique to edit the genes of twin girls reportedly to prevent them from contracting HIV infection (Ma et al., 2019). The controversial research raised a range of ethical questions that prompted the Chinese government to introduce new laws and regulatory measures designed to improve the ethical assessment of research projects (Ma et al., 2019, Wang and Yang, 2019, Cyranoski, 2019a).

In the lead up to the international outcry from He Jiankui's research, scientific institutions strove to develop recommendations to facilitate decision-making for the responsible use of human genome-editing research. This occurrence led to two international summits on human gene editing, one in Washington, D.C., in December 2015, and another at the University of Hong Kong, in November 2018. The first was co-organized by the U.S. Academies of Sciences, Engineering, and Medicine, the Chinese Academy of Sciences, and the U.K.'s Royal Society. The second was co-organized by the U.S. Academies of Sciences, Engineering, and Medicine, the U.K.'s Royal Society, and the Academy of Sciences of Hong Kong. Reactions to the gene editing scandal from China included an additional demand from the scientific community for a multilateral treaty on gene editing, 
backed by strong domestic regulatory measures (Ma et al., 2019, Aquino-Jarquin, 2019).

More recently, in February of 2019, the World Health Organization established a global, multi-disciplinary expert panel, comprising members from all seven regions of the world, to analyze the scientific, ethical, social and legal issues associated with human somatic and germline genome editing (Advisory Committee on Developing Global Standards for Governance and Oversight of Human Genome Editing) (2019). The panel was asked to look into and make recommendations on appropriate standards of governance and oversight at all levels-nationally, regionally, and globally-for the editing of human genome. The standards will then pave the way for an international framework under which scientists should perform research and clinical applications of gene editing, one, as the panel summarized in a report after its inaugural meeting, that will be scalable, sustainable, and focused to "work in parts of the world," countries like $\mathrm{BH}$ no question included, "where there is traditionally weaker regulation of scientific and clinical research and practice, and where genome editing may not yet be pursued with great intensity" (ibid). Going further, the scientific community has called for clear consensus, as well as enactment and enforcement of strict laws globally for the use of human genome editing in medical treatments (Li et al., 2019).

However, despite these laudable international efforts, reports on gene editing involving inappropriate use of CRISP-Cas9 still abound. One recently, conducted in China, involved use of geneedited stem cells in patient with acute lymphoblastic leukemia who was infected with HIV (Xu et al., 2019). Although the researchers claimed a lack of off-target effects of gene editing in this patient, it appears that the study design was cleverly calibrated to give a sense of propriety that minimized its unethical features. Another reported research, this one from Russia, involved Denis Rebrikov, a Russian molecular biologist, who plans to perform gene editing in women with HIV by using a modified version of the technique used by He Jiankui, the Chinese biophysicist in 2018, to produce gene-edited embryos (Cyranoski, 2019b).

Use of genome editing to amend human genomes, today facilitated by the technology of CRISPR-Cas9, raises serious health and ethical concerns, particularly if changes are made to genes in egg or sperm cells (germline cells) or in the genes of an embryo through CRISPR-Cas9 that could be passed to future generations (Howard et al., 2018). Tinkering with the reproductive cells constitutes inherently unsafe human experimentation also effectively irreversible that could put any resulting children at risk of harm. Attempts to genetically engineer future children and generations could be unsafe, medically unnecessary, and immensely damaging to social justice, human dignity, and human rights. Instructively, one recent study indicated that persons with two disabled copies of the CCR5 gene, which was targeted in both of previous studies in China (Ma et al., 2019, June, 2019), risk having accidentally shorter life spans (Wei and Nielsen, 2019).

These occurrences make these unethical changes questionable by diverse individuals and groups, including religious organizations (Al-Balas et al., 2019, Isa et al., 2019). It is also because of these and related concerns that the Japan Society of Gene Therapy and the American Society for Gene and Cell Therapy called for a ban on clinical research of human germline gene editing until its potential risks are broadly assessed (Friedmann et al., 2015). Going further, earlier this year a group of prominent scientists and bioethicists from seven countries called for a global moratorium on germline editing (Lander et al., 2019). Tracking all these concerns, about 30 nations currently have legislation that bars all clinical uses of germline engineering (Araki and Ishii, 2014).

\section{Genetic testing in Bosnia and Herzegovina}

Analyzing the human genome of an individual allows a physician to determine the causes of the disease in question, the chances of its development, and the possibility of the condition in question being successfully treated by gene therapy or editing. Thus, genetic testing and interpretation of genetic data represent a remarkable opportunity, but also as well poses a challenge for this and other societies. Increased availability of testing services signifies increased access to those benefits by patients.

Genetic testing in Bosnia and Herzegovina is mostly performed in clinical settings for three purposes: diagnostic, research, and basic human genetic research (Valjan, 2012). Major institutions in $\mathrm{BH}$ which offer genetic testing are the Clinical Center of the University of Sarajevo, the Institute for Genetic Engineering and Biotechnology at the University of Sarajevo, the University Clinical Center in Banja Luka, and the University Clinical Center in Tuzla. The tests are available to patients through physician referral and cover medical conditions, such as prenatal DNA characterization, thrombophilia and breast cancer risk, and genotyping of the spectrum of inherited disorders through cooperation with laboratories specialized in detecting rare hereditary diseases. Recently, several clinical studies reported the use of genetic tests for improved diagnosis of different diseases in $\mathrm{BH}$ population, such as rheumatoid arthritis (Klimenta et al., 2019), Type 2 diabetes (Semiz et al., 2014, Semiz et al., 2010, Bego et al., 2019, Dujic et al., 2016, Semiz et al., 2011), posttraumatic stress disorder (Kucukalic et al., 2019), psychiatric (Memic et al., 2018), and rare neurodegenerative disorders (Begic et al., 2019). These developments suggest an increased interest in clinical application of genetic testing in $\mathrm{BH}$. Furthermore, awareness of rare disease is on the rise in $\mathrm{BH}$ with recent programs and strategies being adopted to meet the growing demands for treating these often life-threatening and debilitating diseases (Guzvic et al., 2018). Since certified genetic laboratory for the complex diagnostic testing appears to be still lacking in $\mathrm{BH}$, genetic tests for complex diseases are performed in collaboration with the certified laboratories outside the country (Valjan, 2012). An additional challenge is the apparent availability of diagnostic and genetic counseling services for only a few rare diseases. The result is that current efforts in the laboratories which treat these illnesses confine their activities to advancing the level of knowledge and professional skills of physicians in prevention and early diagnosis of rare diseases, as well as on increasing the number of highly specialized personnel in the field of clinical genetics (Guzvic et al., 2018).

In addition to the genetic testing offered at clinics in $\mathrm{BH}$, there are several private labs offering direct-to-consumer (DTC) genetic tests that are providing a way to bypass the traditional healthcare system. DTC genetic tests, which emerged in the early 2000s, allow these "patients" to access their genetic information often without an adequate physician's referral. Consequently, genetic information is becoming increasingly available to the general public, often without adequate awareness of the health risk information that is sold without genetic counseling (Borry et al., 2010, Collins et al., 2011, Middleton et al., 2017). In sum, many DTC genetic testing companies are not providing their consumers with appropriate pre-genetic and post-genetic counseling and even those that do, are raising concerns regarding the mode and quality of genetic counseling that they offer.

Although the importance of the results and the information obtained from genetic test results is undoubtedly valuable for the future, the expensive technology - in many cases amounting to more than an average salary in $\mathrm{BH}$ - pose an obstacle for many $\mathrm{BH}$ citizens wanting to be tested. A recent survey of the perceptions of health science students regarding pharmacogenomics (PG) and precision medicine showed that students' response on 
how much money they are willing to spend to use genetic test was related to their family income, with students from low-income families being more willing to bypass a test, compared to those from "wealthier" families (Mahmutovic et al., 2018). Equally, price was a main consideration for many stakeholders in deciding whether or not to introduce a new technology or drug or provide reimbursement to patients (Guzvic et al., 2017). This is consistent with another study which spelled out the major barriers to global implementation of genomic medicine which, in addition to high costs and related factors (such as lack of reimbursement), identified limited access to reliable standardized genotyping or sequencing platforms as obstacles (Manolio et al., 2015).

Studies found that countries with limited research sources deserve a chance also to air their opinions in global decisions regarding public access and benefits from commercialized products, such as those related to genetic testing (Ndebele and Musesengwa, 2008). International cooperation through large research consortia and distribution of information in the areas of health information technology, genomics, pharmacogenomics, education, professional development, and policy and regulatory issues seems to be key to the future for efficient clinical implementation of precision medicine worldwide (Manolio et al., 2015). In sum, multiple challenges confront genetic testing, among them quality assurance and certification of laboratories for genetic testing, dearth of educated medical personnel (such as genetic counselors, physicians, and psychologists) to provide genetic counsel, and interpret the results from genetic tests, as well as by socioeconomic barriers, foremost of which is the high cost of genetic testing.

\section{Genetic counseling in Bosnia and Herzegovina}

Because different individuals respond differently to genetic test results, it is essential for individuals to have proper counseling to help them understand the meaning and significance of the test results related to their own health risks and treatment options (Winkler and Wiemann, 2016, Howard and Borry, 2013). A recent study by McCuaig et al, suggested that traditional inperson genetic counseling is associated with higher acceptance of genetic testing and patient satisfaction as compared to other alternative methods by telephone or group genetic counseling (Mccuaig et al., 2018). We live in an era when the public healthcare system is being increasingly asked to provide interpretation and counseling related to genetic information generated privately or at the clinic.

The Additional Protocol to the Convention on Human Rights and Biomedicine mandate that genetic testing for health purposes should be conducted under individualized medical supervision, accompanied by genetic counseling (Lwoff, 2009). The treaty sets forth principles related to quality of genetic service and genetic counseling, including the requirement that tests predictive of genetic diseases should include appropriate counseling to minimize misunderstanding of the results of genetic testing and related concerns by patients, such as potential anxiety, embarrassment, discrimination, and stigma if genetic information is inappropriately disclosed (Brothers and Rothstein, 2015). Results of a recent $\mathrm{BH}$ survey demonstrated that almost half of respondents were worried about the possibility that genetic test results may be passed to unauthorized persons (Mahmutovic et al., 2018). Revealingly, when respondents were asked who among a list of healthcare professionals should have access to their genetic information, about half of all respondents selected a genetic counselor (Mahmutovic et al., 2018).

Genetic counseling is being recently introduced at the major clinical centers in $\mathrm{BH}$, where this service seems to be performed mostly by physicians or subspecialist in genetic clinical settings (e.g., prenatal diagnosis along with amniocentesis). Few genetic testing private companies or labs in $\mathrm{BH}$ provide genetic counseling services. And for those who do, information regarding the educational backgrounds of physicians or other health professionals who provide these services and interpretation of genetic test results are often not provided at the website of these companies or labs. Some of these institutions perform genetic analysis in certified laboratories outside $\mathrm{BH}$, while the results of these tests are delivered orally to patients and then subsequently shared with their physicians. In some private companies or labs, counseling is performed via Skype with the translator by certified genetic counselors from the partner companies outside $\mathrm{BH}$. However, a recent study found that although there are institutions in $\mathrm{BH}$ that have developed technical and personnel infrastructure for implementing more advanced genetic diagnostics services, these institutions are not financed by the mandatory health insurance funds (Guzvic et al., 2018). The occurrence makes it difficult for these services to be used by the $\mathrm{BH}$ population (ibid).

It is not clear what type of education and training healthcare professionals who currently provide genetic counseling at $\mathrm{BH}$ clinics and private laboratories have received. Several studies reported that physicians are not always equipped with the knowledge related to genetic tests and that they might not feel competent to interpret the results of genetic tests (Selkirk et al., 2013, Hauser et al., 2018, Bernhardt et al., 2012, Klitzman et al., 2013, Mcgowan et al., 2014). Similarly, results of recent surveys on physicians' attitudes in $\mathrm{BH}$ toward personalized medicine indicate that majority of these physicians do not feel comfortable interpreting results of genetic tests (unpublished data). Thus, to minimize errors in the assessment of health risk and promote disease prevention and treatment options, it is imperative to improve the education of physicians about appropriate ways to utilize genetic tests. In addition to point-of-care learning and clinical decision support systems developed to provide physicians with information regarding pharmacogenetic tests and personalized medicine (O'donnell et al., 2017, Hinderer et al., 2017), there are also learning opportunities, such as online modules and participatory learning strategies to enhance their knowledge on various aspects of genomic medicine (Haga et al., 2019). Studies also indicate that, to facilitate their active participation in the establishment of processes for health technology assessment in the country, future health professionals in $\mathrm{BH}$ should be educated on pharmaco-economics (Catic and Skrbo, 2013).

Still on genetic counseling, another impediment to improving current $\mathrm{BH}$ practices is the lack of university-level education in the field. Recent studies unearthed vast disparities between European countries and $\mathrm{BH}$ regarding standards for education, practice, and registration of genetic counselors (Paneque et al., 2016). The European Board of Medical Genetics has recommended education at the master's level as the appropriate academic and professional standards for genetic counselors (Paneque et al., 2016), a recommendation we believe $\mathrm{BH}$ authorities should consider with a view to applying it.

\section{Public engagement in Bosnia and Herzegovina}

Activities relating to public engagement should strive to go beyond informing and consulting individuals, and include promoting the knowledge society needs to embrace emerging biotechnologies. Recent survey of popular attitudes in Belgium on genetics and genetic testing (Chokoshvili et al., 2017) indicate that acknowledging the concerns of the general public is key to ensuring ethically-reliable and socially-acceptable application of novel genetic technologies. To protect human subjects while engendering public trust, there is serious need for institutional frameworks to ensure that the application of new technologies, 
such as CRISPR-Cas9 at the focus of this article, follow the highest ethical standards (Caplan, 2019). Public engagement should be the tool for popular upholding of bioethical principles in scientific research in gene editing necessary for increased awareness among various stakeholders, including the scientific communities, healthcare providers, government institutions, and the general public regarding the safety of genome editing technologies. To reach a broad societal consensus on gene editing, there is need for domestic and international standards that spell out the rights and responsibilities of scientists, policy makers, public, and other stakeholders (Jasanoff and Hurlbut, 2018).

Based on the Strategic Health Development Plan between 2008 and 2018, adopted by the BH government, Bosnia and Herzegovina endeavors to comply with modern trends in science, focused around a range of factors embedded in healthcare, including stimulating the development of public-private partnership, investments in human resources and training for health professionals, and overall quality assurance. Going forward, $\mathrm{BH}$ became a member of the Management Committee of the COST Action-Citizen's Health through Public-Private Initiatives: Public Health, Market and Ethical Perspectives (CHIPME) in which forum and work it participated actively. The program provided a forum for review and revisit of existing ethical and regulatory frameworks in participating countries. It has also served to enhance interaction between public and private actors by creating a community of researchers and stakeholders aimed at bringing together critical expertize from multiple fields, such as bioethics, social studies of science and technology, genetic technology, information and communication technology, who band together in deliberation on patient-centered initiatives. Our recent survey of the $\mathrm{BH}$ general public regarding their attitudes toward genetic testing, genetic counseling and gene editing produced intriguingly mixed results. From their answers, the respondents appeared to be aware of these novel tools of precision medicine, but when asked whether they would design genes of their children, their responses were positive if and only if the technology would be used to protect those children from certain genetically-predisposed diseases (Semiz, 2016).

Public education about genomics is the key to widespread application of genetic testing, genetic counseling, and gene editing in the $\mathrm{BH}$ healthcare system (Mahmutovic et al., 2018). Results from a cross-sectional study published in 2018, in which one of the coauthors participated, unearthed the positive attitude of biomedical students in Bosnia and Herzegovina toward genetic testing and counseling, including the influence of pharmacogenomic education for more efficient translation of precision medicine into clinical practice (Mahmutovic et al., 2018). The study examined the perceptions of students from different universities in $\mathrm{BH}$ toward precision medicine, pharmacogenomic education, and the corresponding ethical, legal, and social implications. It was based on a survey of 559 students from various biomedical fields, including bioengineering, genetics, health studies, medicine, and pharmacy. Results from the study showed that $50 \%$ of the students heard about personal genome testing companies, $69 \%$ consider having a genetic test done, $57 \%$ agreed that PM represents a promising healthcare model, and $40 \%$ believed that their study program is well designed for understanding the intersection and significance of PG/PM in medical practice.

Majority of participants in our more recent survey showed positive attitudes toward human genome editing and would support treatment of conditions through the use of gene editing (unpublished data). At the same time, they also shared their major concerns related to gene editing, including safety procedure with possible irreparable risks for fetal development, possible abuse of human enhancement, potential harmful effects on future generations, and a lack of consent for genetic modifications that could affect future human generations. Many respondents also expressed their belief that the general public in $\mathrm{BH}$ should be more informed about new medical and scientific advancements, such as gene editing, and that the most effective ways for education and public engagement are educational programs, media (Internet, newspapers, TV shows), and brochures offered by health institutions. The findings are consistent with the recent paper by Dressler and his colleagues, which suggested that roundtable discussions, a body of experts' discussions, workshops, and symposia are needed to bring together key interdisciplinary stakeholders in academia, government, profit, and nonprofit organizations to create programs of genomic education for the public (Dressler et al., 2014).

To enhance understanding of clinically-relevant concepts in genetics and physicians' confidence in reviewing genetic information, it is necessary to increase collaboration among stakeholders, including the general public, universities, health workers and their associations, healthcare institutions, as well as to incorporate more training and continued education topics related to genetic testing. Patients' organizations must also play an important role by providing support and assistance to patients by, for example, performing genetic tests on rare diseases and focusing on advocacy at all levels of $\mathrm{BH}$ government (Guzvic et al., 2018). Furthermore, the associations of health professions should take a more active role in organizing continued professional education in various aspects of genomic medicine in $\mathrm{BH}$ health centers and clinics. This would be consistent with the need to define the values of good medical practice emphasized in the Strategic Health Development plan between 2008 and 2018 in Bosnia and Herzegovina (Bh, 2008).

\section{Legal framework}

Several laws and regulations have been adopted in $\mathrm{BH}$ within the context of reform of the healthcare system. Two of these legislation, the healthcare act and health insurance act, are enacted by all the units comprising the $\mathrm{BH}$ healthcare system, including the Federation of Bosnia and Herzegovina and its ten Cantons, Republika Srpska, and the Brčko District of Bosnia and Herzegovina. Between them, these two sets of law specify the conditions under which persons become eligible to enjoy healthcare benefits, and guarantee $\mathrm{BH}$ citizens and residents a basic healthcare package. Specifically, the healthcare law governs the principle, organization, and delivery of healthcare services, while the health insurance law regulates insurance as part of a social insurance system based on certain key principles like equal access and equity. These laws are helping to protect the privacy and dignity of patients, while keeping their data confidential (Valjan, 2012).

In line with European orientation, BH's Strategic Health Development plan between 2008 and 2018 focuses on quality of healthcare services, as well as measures designed to promote good health and prevent diseases. Additional avenues for improvement of the healthcare system in $\mathrm{BH}$ include, but are not limited to, increased integration of healthcare systems in $\mathrm{BH}$ and improved professional communication across the various institutions and levels of healthcare (Novo et al., 2019), improved access to healthcare services guaranteed by the compulsory health insurance, improved coordination between educational system, labor market and healthcare system, more equity in the distribution of health products and services, more preventive medicine, increased public-private partnership in healthcare delivery, and more private-sector participation in the healthcare systems (Federation of Bosnia and Herzegovina, 2008) (Bh, 2008). BH needs a separate law on genetic testing (Valjan, 2012), together with regulations on maintaining and servicing medical and 
diagnostic equipment and their standardization, all of which adds to the quantity and quality of healthcare delivery (Federation of Bosnia and Herzegovina, 2008).

$\mathrm{BH}$ decision makers at all levels should ensure that socioeconomic differences, including cultural and administrative practices, do not impede access to optimal healthcare services for $\mathrm{BH}$ citizens, including matters bordering on precision medicine of the type this article analyzed. They must also strive to realize standards for citizens, whether in healthcare delivery, research, or general educational services, that do not lag behind the rest of Europe. Consistent with the assessment of the Strategy Health Development Plan between 2008 and 2018, it is important that these policymakers align the legal framework relating to genetics with the needs of the community while complying with principles from European intergovernmental organizations, like the Council of Europe and the European Union, the first of which $\mathrm{BH}$ is a member and the latter of whom it aspires to join. The route to reaching these governance goals will be through well-timed legislation, level-headed implementation, and diligent legislative oversight of the work of administrative agencies.

\section{Conclusion}

To optimize medical treatment and combat the inadequate access to healthcare in many parts of the world today, including Bosnia and Herzegovina, Citizens Health through Public-Private Initiatives is an idea whose time has come that also keys into the scientific, legal, and ethical ramifications of genetic testing, genetic counseling, genome editing, and related tools of precision medicine. CRISPR-Cas9 is a young gene-editing technique with still many unknowns. Possibilities and challenges of its clinical applications appear to be similar to those that other countries face in the eve of the scandal from China, galvanized by CRISPR-Cas9, regarding manipulation of human DNA. However, there are also additional challenges and constraints unique to $\mathrm{BH}$ that this paper addresses, with the clear need for effective laws and public engagement, designed to protect and educate the public on the benefits and possible ethical and other pitfalls of new technologies. To better understand the potential array of beneficial and adverse effects of these technologies in human subjects, there is need for broader research and educational initiatives. By allocating healthcare funds, public health policy should ensure accessibility, social justice, and the use of these novel medical services to improve public health. This paper shows the influence of recent global developments revolved around possibilities of patient-tailored medical practice in $\mathrm{BH}$, while simultaneously contributing insights and perspectives from the country to these global developments.

\section{Data availability}

Data sharing is not applicable to this article, as no datasets were generated or analyzed during the study.

Received: 25 July 2019; Accepted: 8 October 2019;

Published online: 29 October 2019

\section{References}

Advisory Committee on Developing Global Standards for Governance and Oversight of Human Genome Editing: Report of the First Meeting (2019) World Health Organization. https://www.who.int/ethics/topics/human-genomeediting/GenomeEditing-FirstMeetingReport-FINAL.pdf. Accessed Sep 2019

Adams SA, Petersen C (2016) Precision medicine: opportunities, possibilities, and challenges for patients and providers. J Am Med Inf Assoc 23:787-790
Al-Balas QA, Dajani R, Al-Delaimy WK (2019) Traditional Islamic approach can enrich CRISPR twins debate. Nature 566:455

Aquino-Jarquin G (2019) Tighten up Mexico's regulations on human gene editing. Nature 566:455

Araki M, Ishii T (2014) International regulatory landscape and integration of corrective genome editing into in vitro fertilization. Reprod Biol Endocrinol $12: 108$

Baliou S, Adamaki M, Kyriakopoulos AM, Spandidos DA, Panayiotidis M, Christodoulou I, Zoumpourlis V (2018) CRISPR therapeutic tools for complex genetic disorders and cancer (Review). Int J Oncol 53:443-468

Begic E, Bradaric H, Begic Z, Dobraca A (2019) Lafora disease during a seven-year period, Bosnian and Herzegovinian experience. Iran J Child Neurol 13:115-120

Bego T, Causevic A, Dujic T, Malenica M, Velija-Asimi Z, Prnjavorac B, Marc J Nekvindova J, Palicka V, Semiz S (2019) Association of FTO Gene Variant (rs8050136) with Type 2 diabetes and markers of obesity, glycaemic control and inflammation. J Med Biochem 38:153-163

Belisle-Pipon JC, Vayena E, Green RC, Cohen IG (2019) Genetic testing, insurance discrimination and medical research: what the United States can learn from peer countries. Nat Med 25:1198-1204

Bernhardt BA, Zayac C, Gordon ES, Wawak L, Pyeritz RE, Gollust SE (2012) Incorporating direct-to-consumer genomic information into patient care: attitudes and experiences of primary care physicians. Per Med 9:683-692

Federation of Bosnia and Herzegovina (2008) Strategic plan for health care development in the Federation of Bosnia and Herzegovina between 2008 and 2018 http://www.nationalplanningcycles.org/sites/default/files/country_docs/Bosnia\% 20and\%20Herzegovina/bosnia_herzegovina_strategic_plan_for_health_care_ development_2008-2018.pdf

Bikard D, Hatoum-Aslan A, Mucida D, Marraffini LA (2012) CRISPR interference can prevent natural transformation and virulence acquisition during in vivo bacterial infection. Cell Host Microbe 12:177-186

Bilichak A, Gaudet D, Laurie J (2020) Emerging genome engineering tools in crop research and breeding. Methods Mol Biol 2072:165-181

Borry P, Cornel MC, Howard HC (2010) Where are you going, where have you been: a recent history of the direct-to-consumer genetic testing market. J Community Genet 1:101-106

Brothers KB, Rothstein MA (2015) Ethical, legal and social implications of incorporating personalized medicine into healthcare. Per Med 12:43-51

Canedo JR, Miller ST, Myers HF, Sanderson M (2019) Racial and ethnic differences in knowledge and attitudes about genetic testing in the US: systematic review. J Genet Couns 28:587-601

Caplan A (2019) Getting serious about the challenge of regulating germline gene therapy. PLoS Biol 17:e3000223

Catic T, Skrbo S (2013) Pharmacoeconomic education for pharmacy students in bosnia and herzegovina. Mater Sociomed 25:282-285

Chokoshvili D, Belmans C, Poncelet R, Sanders S, Vaes D, Vears D, Janssens S, Huys I, Borry P (2017) Public views on genetics and genetic testing: a survey of the general public in Belgium. Genet Test Mol Biomark 21:195-201

Collins RE, Wright AJ, Marteau TM (2011) Impact of communicating personalized genetic risk information on perceived control over the risk: a systematic review. Genet Med 13:273-277

Cyranoski D (2019a) The CRISPR-baby scandal: what's next for human geneediting. Nature 566:440-442

Cyranoski D (2019b) Russian biologist plans more CRISPR-edited babies. Nature 570:145-146

Doudna JA, Charpentier E (2014) Genome editing. The new frontier of genome engineering with CRISPR-Cas9. Science 346:1258096

Dressler LG, Jones SS, Markey JM, Byerly KW, Roberts MC (2014) Genomics education for the public: perspectives of genomic researchers and ELSI advisors. Genet Test Mol Biomark 18:131-140

Duardo-Sanchez A, De Miguel Beriain I (2018) Personalized medicine and medicinal chemistry: toward a legal framework in the European Union. Curr Top Med Chem 18:2165-2173

Dujic T, Causevic A, Bego T, Malenica M, Velija-Asimi Z, Pearson ER, Semiz S (2016) Organic cation transporter 1 variants and gastrointestinal side effects of metformin in patients with Type 2 diabetes. Diabet Med 33:511-514

Friedmann T, Jonlin EC, King NMP, Torbett BE, Wivel NA, kaneda Y, Sadelain M (2015) ASGCT and JSGT joint position statement on human genomic editing. Mol Ther 23:1282

Guzvic V, Catic T, Kostic M (2017) Health technology assessment in centralEastern and South Europe Countries: Bosnia and Herzegovina. Int J Technol Assess Health Care 33:390-395

Guzvic V, Stojakovic N, Jusufovic R, Catic T (2018) Rare diseases and orphan drugs accessibility in Bosnia and Herzegovina. Mater Sociomed 30:297-303

Haga SB, Kim E, Myers RA, Ginsburg GS (2019) Primary care physicians knowledge, attitudes, and experience with personal genetic testing. J Pers Med 9:pii: E29 
Hauser D, Obeng AO, Fei K, Ramos MA, Horowitz CR (2018) Views of primary care providers on testing patients for genetic risks for common chronic diseases. Health Aff (Millwood) 37:793-800

Heintze J, Luft C, Ketteler R (2013) A CRISPR CASe for high-throughput silencing. Front Genet 4:193

Hinderer M, Boeker M, Wagner SA, Lablans M, Newe S, Hulsemann JL, Neumaier M, Binder H, Renz H, Acker T, Prokosch HU, Sedlmayr M (2017) Integrating clinical decision support systems for pharmacogenomic testing into clinical routine-a scoping review of designs of user-system interactions in recent system development. BMC Med Inf Decis Mak 17:81

Howard HC, Borry P (2013) Survey of European clinical geneticists on awareness, experiences and attitudes towards direct-to-consumer genetic testing. Genome Med 5:45

Howard HC, Van El CG, Forzano F, Radojkovic D, Rial-Sebbag E, De Wert G, Borry P, Cornel MC, Public and Professional Policy Committee of the European Society of Human, Genetics (2018) One small edit for humans, one giant edit for humankind? Points and questions to consider for a responsible way forward for gene editing in humans. Eur J Hum Genet 26:1-11

Iriart JAB (2019) Precision medicine/personalized medicine: a critical analysis of movements in the transformation of biomedicine in the early 21 st century. Cad Saude Publica 35:e00153118

Isa NM, Zulkifli NA, Man S (2019) Islamic perspectives on CRISPR/Cas9-mediated human germline gene editing: a preliminary discussion. Sci Eng Ethics https://doi.org/10.1007/s11948-019-00098-z. [Epub ahead of print]

Jasanoff S, Hurlbut JB (2018) A global observatory for gene editing. Nature 555:435-437

June $\mathrm{CH}$ (2019) Emerging use of CRISPR technology-chasing the elusive HIV cure. N Engl J Med 381:1281-1283

Kc M, Steer CJ (2019) A new era of gene editing for the treatment of human diseases. Swiss Med Wkly 149:w20021

Khan SH (2019) Genome-editing technologies: concept, pros, and cons of various genome-editing techniques and bioethical concerns for clinical application. Mol Ther Nucleic Acids 16:326-334

Klimenta B, Nefic H, Prodanovic N, Jadric R, Hukic F (2019) Association of biomarkers of inflammation and HLA-DRB1 gene locus with risk of developing rheumatoid arthritis in females. Rheumatol Int https://doi.org/10.1007/ s00296-019-04429-y. [Epub ahead of print]

Klitzman R, Chung W, Marder K, Shanmugham A, Chin LJ, Stark M, Leu CS, Appelbaum PS (2013) Attitudes and practices among internists concerning genetic testing. J Genet Couns 22:90-100

Kucukalic S, Feric Bojic E, Babic R, Avdibegovic E, Babic D, Agani F, Jakovljevic M, Kucukalic A, Bravo Mehmedbasic A, Sabic Dzananovic E, Marjanovic D, Kravic N, Pavlovic M, Aukst Margetic B, Jaksic N, Cima Franc A, Rudan D, Haxhibeqiri S, Goci Uka A, Hoxha B, Haxhibeqiri V, Muminovic UMIHANIC M, Sinanovic O, Bozina N, Ziegler C, Wolf C, Warrings B, Domschke K, Deckert J, Dzubur Kulenovic A (2019) Genetic susceptibility to posttraumatic stress disorder: analyses of the oxytocin receptor, retinoic acid receptor-related orphan receptor a and cannabinoid receptor 1 genes. Psychiatr Danub 31:219-226

Lander ES, Baylis F, Zhang F, Charpentier E, Berg P, Bourgain C, Friedrich B, Joung JK, Li J, Liu D, Naldini L, Nie JB, Qiu R, Schoene-Seifert B, Shao F, Terry S, Wei W, Winnacker EL (2019) Adopt a moratorium on heritable genome editing. Nature 567:165-168

Li JR, Walker S, Nie JB, Zhang XQ (2019) Experiments that led to the first geneedited babies: the ethical failings and the urgent need for better governance. J Zhejiang Univ Sci B 20:32-38

Lwoff L (2009) Council of Europe adopts protocol on genetic testing for health purposes. Eur J Hum Genet 17:1374-1377

Ma Y, Zhang L, Qin C (2019) The first genetically gene-edited babies: It's "irresponsible and too early". Anim Model Exp Med 2:1-4

Mahmutovic L, Akcesme B, Durakovic C, Akcesme FB, Maric A, Adilovic M, Hamad N, Wjst M, Feeney O, Semiz S (2018) Perceptions of students in health and molecular life sciences regarding pharmacogenomics and personalized medicine. Hum Genomics 12:50

Manolio TA, Abramowicz M, Al-Mulla F, Anderson W, Balling R, Berger AC, Bleyl S, Chakravarti A, Chantratita W, Chisholm RL, Dissanayake VH, Dunn M, Dzau VJ, Han BG, Hubbard T, Kolbe A, Korf B, Kubo M, Lasko P, Leego E, Mahasirimongkol S, Majumdar PP, Matthijs G, Mcleod HL, Metspalu A, Meulien P, Miyano S, Naparstek Y, O'rourke PP, Patrinos GP, Rehm HL, Relling MV, Rennert G, Rodriguez LL, Roden DM, Shuldiner AR, Sinha S, Tan P, Ulfendahl M, Ward R, Williams MS, Wong JE, Green ED, Ginsburg GS (2015) Global implementation of genomic medicine: We are not alone. Sci Transl Med 7:290ps13

Mccuaig JM, Armel SR, Care M, Volenik A, Kim RH, Metcalfe KA (2018) Nextgeneration service delivery: a scoping review of patient outcomes associated with alternative models of genetic counseling and genetic testing for hereditary cancer. Cancers 10:E435
Mcgowan ML, Fishman JR, Settersten Jr RA, Lambrix MA, Juengst ET (2014) Gatekeepers or intermediaries? The role of clinicians in commercial genomic testing. PLoS ONE 9:e108484

Mei Y, Wang Y, Chen H, Sun ZS, Ju XD (2016) Recent progress in CRISPR/Cas9 technology. J Genet Genomics 43:63-75

Memic A, Streit F, Hasandedic L, Witt SH, Strohmaier J, Rietschel M, Oruc L (2018) Neurocognitive endophenotypes of schizophrenia and bipolar disorder and possible associations with FKBP variant rs3800373. Med Arch 72:352-356

Mensah GA, Jaquish C, Srinivas P, Papanicolaou GJ, Wei GS, Redmond N, Roberts MC, Nelson C, Aviles-Santa L, Puggal M, Green Parker MC, Minear MA, Barfield W, Fenton KN, Boyce CA, Engelgau MM, Khoury MJ (2019) Emerging concepts in precision medicine and cardiovascular diseases in racial and ethnic minority populations. Circ Res 125:7-13

Middleton A, Mendes A, Benjamin CM, Howard HC (2017) Direct-to-consumer genetic testing: where and how does genetic counseling fit? Per Med 14:249-257

National Academies of Sciences, Engineering, and Medicine (2018) Understanding Disparities in Access to Genomic Medicine: Proceedings of a Workshop. Washington, DC: The National Academies Press. https://doi.org/10.17226/ 25277

Ndebele P, Musesengwa R (2008) Will developing countries benefit from their participation in genetics research? Malawi Med J 20:67-69

Novo A, Knezevic B, Omerbegovic B, Tafi Z, Kerleta-Tuzovic V (2019) Measures to improve integration of Healthcare in Federation of Bosnia and Herzegovina. Mater Sociomed 31:71-74

O'donnell PH, Wadhwa N, Danahey K, Borden BA, Lee SM, Hall JP, Klammer C, Hussain S, Siegler M, Sorrentino MJ, Davis AM, Sacro YA, Nanda R, Polonsky TS, Koyner JL, Burnet DL, Lipstreuer K, Rubin DT, MULCAHY C, Strek ME, Harper W, Cifu AS, Polite B, Patrick-Miller L, Yeo KT, Leung E, Volchenboum SL, Altman RB, Olopade OI, Stadler WM, Meltzer DO, Ratain MJ (2017) Pharmacogenomics-based point-of-care clinical decision support significantly alters drug prescribing. Clin Pharm Ther 102:859-869

Paneque M, Moldovan R, Cordier C, Serra-Juhe C, Feroce I, Lambert D, Bjornevoll I, Skirton H (2016) Development of a registration system for genetic counsellors and nurses in health-care services in Europe. Eur J Hum Genet 24:312-314

Porteus MH (2019) A new class of medicines through DNA editing. N Engl J Med 380:947-959

Sankar PL, Parker LS (2017) The Precision Medicine Initiative's All of US Research Program: an agenda for research on its ethical, legal, and social issues. Genet Med 19:743-750

Selkirk CG, Weissman SM, Anderson A, Hulick PJ (2013) Physicians' preparedness for integration of genomic and pharmacogenetic testing into practice within a major healthcare system. Genet Test Mol Biomark 17:219-225

Semiz S (2016) Celebration of World Bioethics Day 2016 in Sarajevo, Bosnia and Herzegovina https://bhbioethics.ius.edu.ba/sites/default/files/link_10-wbd_ 2016_report_bh_unit_nov_2016.pdf: International University of Sarajevo, 2019

Semiz S, Dujic T, Ostanek B, Prnjavorac B, Bego T, Malenica M, Marc J, Causevic A (2010) Analysis of CYP2C $9^{*} 2$, CYP 2 C $19^{*} 2$, and CYP $26^{*} 4$ polymorphisms in patients with type 2 diabetes mellitus. Bosn J Basic Med Sci 10:287-91

Semiz S, Dujic T, Ostanek B, Velija-Asimi Z, Prnjavorac B, Bego T, Malenica M, Mlinar B, Heljic B, Marc J, Causevic A (2011) Association of NAT2 polymorphisms with type 2 diabetes in a population from Bosnia and Herzegovina. Arch Med Res 42:311-317

Semiz S, Dujic T, Velija-Asimi Z, Prnjavorac B, Bego T, Ostanek B, Marc J, Causevic A (2014) Effects of melatonin receptor 1B gene variation on glucose control in population from Bosnia and Herzegovina. Exp Clin Endocrinol Diabetes 122:350-355

Shah SZ, Rehman A, Nasir H, Asif A, Tufail B, Usama M, Jabbar B (2019) Advances in research on genome editing crispr-cas9 technology. J Ayub Med Coll Abbottabad 31:108-122

Shim G, Kim D, Park GT, Jin H, Suh SK, Oh YK (2017) Therapeutic gene editing: delivery and regulatory perspectives. Acta Pharm Sin 38:738-753

Valjan V (2012) Integrative bioethics faced with the challenges of biotechnology: collection of articles from the third international bioethical symposium in Bosnia and Herzegovina; Bioetičko društvo u $\mathrm{BH}$

Wang H, Yang H (2019) Gene-edited babies: What went wrong and what could go wrong. PLoS Biol 17:e3000224

Wei X, Nielsen R (2019) CCR5-32 is deleterious in the homozygous state in humans. Nat Med 25:909-910

White MK, Khalili K (2016) CRISPR/Cas9 and cancer targets: future possibilities and present challenges. Oncotarget 7:12305-12317

Winkler EC, Wiemann S (2016) Findings made in gene panel to whole genome sequencing: data, knowledge, ethics - and consequences? Expert Rev Mol Diagn 16:1259-1270 
Wright AV, Nunez JK, Doudna JA (2016) Biology and applications of CRISPR systems: harnessing nature's toolbox for genome engineering. Cell 164:29-44

Xu L, Wang J, Liu Y, Xie L, Su B, Mou D, Wang L, Liu T, Wang X, Zhang B, Zhao L, Hu L, Ning H, Zhang Y, Deng K, Liu L, Lu X, Zhang T, Xu J, Li C, Wu H, Deng H, Chen H (2019) CRISPR-edited stem cells in a patient with HIV and acute lymphocytic leukemia. N Engl J Med 381:1240-1247

\section{Acknowledgements}

This article is based on work from COST Action IS1303, "Citizen's Health through public-private Initiatives: Public health, Market and Ethical perspectives," supported by COST (European Cooperation in Science and Technology) (http://www.cost.eu). The authors gratefully acknowledge the research support of the Council of Ministers of Bosnia and Herzegovina, under the Ministry of Civil Affairs, signified by grants to S. Semiz in genetic testing, genetic counseling, and genome editing. They also express their appreciation to all $\mathrm{BH}$ students who participated in the surveys that culminated in this paper, especially to Amina Agovic, International University of Sarajevo student. Last but not least, the authors acknowledge the kind support of the Association of South East European Network for Medical Research (SOVE).

\section{Competing interests}

The authors declare no competing interests.

\section{Additional information}

Correspondence and requests for materials should be addressed to S.S

Reprints and permission information is available at http://www.nature.com/reprints

Publisher's note Springer Nature remains neutral with regard to jurisdictional claims in published maps and institutional affiliations.

Open Access This article is licensed under a Creative Commons Attribution 4.0 International License, which permits use, sharing, adaptation, distribution and reproduction in any medium or format, as long as you give appropriate credit to the original author(s) and the source, provide a link to the Creative Commons license, and indicate if changes were made. The images or other third party material in this article are included in the article's Creative Commons license, unless indicated otherwise in a credit line to the material. If material is not included in the article's Creative Commons license and your intended use is not permitted by statutory regulation or exceeds the permitted use, you will need to obtain permission directly from the copyright holder. To view a copy of this license, visit http://creativecommons.org/licenses/by/4.0/.
\end{abstract}

(C) The Author(s) 2019 